\title{
REM SLEEP DEPRIVATION-INDUCED OXIDATIVE STRESS AND ITS ATTENUATION BY TEPHROSIA PURPUREA (L.,) IN DISCRETE REGIONS OF RAT BRAIN
}

\section{PRAKASH SELVARAJ, ANNADURAI SHANMUGANATHAN, SARAVANAN SELVARAJ, BABUKUMAR MANI, SAKTHIVEL GOVINDRAJ, RAVINDRAN RAJAN*}

Department of Physiology, Dr.A.L.M. PGIBMS, University of Madras, Chennai, Tamil Nadu, India. Email: ravindran89@gamil.com Received: 03 January 2017, Revised and Accepted: 02 February 2018

\begin{abstract}
Objective: The aim of this study is to assess the antioxidant activity of Tephrosia purpurea (TP) in $72 \mathrm{~h}$ REM sleep deprivation (RSD). Nowadays, plants are used as therapeutic agents in the wide range of clinical applications. The present investigation is focused on the antioxidant activity of the ethanolic extract of TP on $72 \mathrm{~h}$ RSD induced changes in discrete regions of rat brain.

Methods: In this study, the plant (leaf) sample collected and ethanolic extraction were done using Soxhlet apparatus. Five groups of Wistar strain male albino rats were used in this study. Each group comprises 6 rats and multiple platform models used for RSD. The values were statistically analyzed using one-way analysis of variance followed by Tukey's post hoc test for multiple comparison methods. The significance level was kept at $p<0.05$. The $72 \mathrm{~h}$ RSD-induced changes in discrete regions were investigated and verified by measuring the activity of superoxide dismutase (SOD), lipid peroxidation (LPO), catalase (CAT), glutathione peroxidase (GPx), levels of reduced glutathione (GSH), Vitamin C, and Vitamin E in different regions of the rat brain, and plasma corticosterone level.
\end{abstract}

Results: This study confirmed that the leaf extract of TP effectively normalized the increased corticosterone, LPO, SOD, CAT, GPx, and decreased GSH, Vitamin C, and Vitamin E levels as a result of $72 \mathrm{~h}$ RSD exposure.

Conclusion: The plant examined and possessed remarkable antioxidant activity; hence, the isolation of compounds from this plant leaves may develop a novel and natural phytomedicine for stress-induced diseases.

Keywords: Antioxidants, Tephrosia purpurea, REM sleep deprivation, Oxidative stress, Corticosterone.

(c) 2018 The Authors. Published by Innovare Academic Sciences Pvt Ltd. This is an open access article under the CC BY license (http://creativecommons. org/licenses/by/4. 0/) DOI: http://dx.doi.org/10.22159/ajpcr.2018.v11i5.24601

\section{INTRODUCTION}

Sleep is essential for normal physiological functions in human and animals; it provides restorations of emotional and physical activity in a manner that is not well established [1]. The average sleep per $24 \mathrm{~h}$ has declined by 1.5 h over the past century [2]. Sleep occurs in two stages: Nonrapid eye movement (NREM) and REM [3]. Evidence from many studies suggests that an important function of sleep is a consolidation of new information into long-term memory. Multiple studies in both humans and rodents reported memory impairments as a result of sleep deprivation (SD) [4]. Human studies show that the total SD for a single night disturbs memory function [5]. In addition, numerous animal studies also shown that 24-96 $\mathrm{h}$ of SD lead to impairment of memory and behavioral changes. Moreover, SD was shown to impair long-term potentiation of the hippocampus, which is one of the main centers for learning and memory function [6]. SD also elevates hippocampal oxidative stress, which reflects on neuronal excitability, cognitive functions, and molecular signaling [7]. SD reduces the expression of transcription and translation synaptic proteins in hippocampus and many regions of the brain [8]. During pregnancy, SD increases the risk of pre-eclampsia, gestational diabetes, intrauterine growth restriction, and the need for cesarean delivery [9]. Cytokines such as tumor necrosis factor-alpha and interleukin 1- beta gene expression increases in the hypothalamus during RSD [10]. SD leads to stroke, obesity, diabetes, osteoporosis, cardiovascular disease, cancer, and permanent cognitive deficits [11].

Tephrosia purpurea (TP) belongs to Fabaceae family, highly branched plant have been used in India as a traditional medicine for the treatment of inflammatory disorders [12], laxative, bleeding disorder, and diuretics [13]. It also has antioxidant activity, according to the Indian indigenous system of medicine. Hence, this present study was focused to evaluate physiological antioxidant defense elements such as lipid peroxidation (LPO), superoxide dismutase (SOD), catalase (CAT), glutathione peroxidase (GPx), reduced glutathione (GSH), and Vitamin $\mathrm{C}$ and Vitamin $\mathrm{E}$ in discrete regions of rat brain.

\section{METHODS}

\section{Animals}

Wistar strain male albino rats (200-250 g) were maintained under standard laboratory conditions with water and food; the animals were handled according to the principles of laboratory care framed by the committee for the purpose of control and supervision of experiments on animals, Government of India. Animal experiments were carried out after getting clearance from the Institutional Animal Ethical Committee (IAEC NO: 54/12/2015).

\section{Experimental protocol}

Animals were divided into five equal groups; each group consists of six animals. The ethanolic extract of TP was used for this study.

- Group - I Control animals were used for studying the baseline values

- Group - II Animals were administered $2 \%$ of Tween 80 as a vehicle

- Group - III Animals were exposed to $72 \mathrm{~h}$ RSD

Group - IV Animals were treated with only an ethanolic extract of TP . $(500 \mathrm{mg} / \mathrm{kg})$ [14] for 18 days and

Group - V Animals pretreated with ethanolic extract of TP for 15 days . +72 h RSD with the same treatment.

\section{Plant collection and extract preparation}

The dried leaves of TP L., were purchased from Government Irula Tribe Women's Welfare Society, Tandarai, Chengalpattu, Tamil Nadu, India- 603001. Bill No: 122/05/2016. The plant material was powdered 
and passed through the sieve (coarse 10/44). About $200 \mathrm{~g}$ of plant powder was extracted with $1000 \mathrm{~mL}$ of $95 \%$ ethanol under reflux by heating over a water bath at $60^{\circ} \mathrm{C}$. The extract was then vacuum dried. The yield of ethanolic extract of TP was $31.23 \%(w / w)$. The suspension of the extracted drug was prepared by dissolving in $2 \%$ Tween 80 before administration to animals [14].

RSD

RSD for $72 \mathrm{~h}$ was induced using the multiple platform models [15]. It was started and ended at the beginning of the light phase, and the room was maintained at the controlled temperature $\left(23 \pm 1^{\circ} \mathrm{C}\right)$ and light-dark cycle (lights on between 07.00 and $19.00 \mathrm{~h}$ ). In this experiment 6 rats from same group placed in a water tank $(120 \mathrm{~cm} \times$ $70 \mathrm{~cm} \times 50 \mathrm{~cm}$ ) containing 10 round platforms (each round platform made up of $7 \mathrm{~cm}$ diameter and $10 \mathrm{~cm}$ height, it was raised $2 \mathrm{~cm}$ above the water level) arranged in two lines and $20 \mathrm{~cm}$ away from each other (edge to edge), in which the rats can move around freely from one platform to another one. Loss of muscle tone at the beginning of each REM (paradoxical) sleep episode causes rats to fell in the water, thus being awakened. During the SD period, the animals had free access to water bottles and chow pellets attaching from a grill located on the top of the chamber. As the animals can move freely within the multiplatform chamber, it has been reported that it has less immobilization stress compared to the single version of platform technique [16].

\section{Biochemical analysis}

The activity of LPO was indirectly estimated by determining the accumulation of thiobarbituric acid reactive substances in the tissue homogenate by the method of Ohkawa et al. [17]. According to Marklund and Marklund [18], the SOD activity was measured as the degree of inhibition of auto-oxidation of pyrogallol at alkaline $\mathrm{pH}$. The activity of CAT was measured as the amount of hydrogen peroxide consumed per minute per milligram of protein by the method of Sinha [19]. GPx level was estimated by measuring the amount of reduced GSH consumed in the reaction mixture according to the method of Rotruck et al. [20]. The reduced GSH level was measured based on the development of relatively stable yellow color, when 200 mM 5, 5' - dithiobis- (2- nitrobenzoic acid) solution was added, according to the method of Moron et al. [21]. Vitamin C was estimated by the method of Omaye et al. [22], and Vitamin E was measured by the method of Desai [23]. The total protein was estimated by the method of Lowry et al. [24], using Bovine serum albumin as standard. The corticosterone level was measured using Elisa kit. (Cusabio, biotech Co Limited, China. C.No.CSB-E07014r).

\section{Statistical analysis}

All data were expressed as the mean \pm standard deviation. The statistical significance was evaluated by one-way analysis of variance using SPSS statistical package version 20.0 (SPSS, Cary, NC, USA). When there is a significant difference, Tukey's multiple comparison tests were performed by fixing the significance at level $\mathrm{p}<0.05$.

\section{RESULT}

\section{Plasma corticosterone}

The plasma corticosterone (d.f. $=4, F=44.132$ ) levels (Fig. 1) was increased in Group-III compared to Group-I control. However, corticosterone levels in Group-V animals were significantly decreased when compared to Group-III after $72 \mathrm{~h}$ RSD exposure.

\section{LPO}

The levels of LPO (Fig. 2) were significantly increased in GroupIII after $72 \mathrm{~h}$ RSD in discrete regions of the brain (hypothalamus [d.f. $=4, \quad F=466.323$ ], hippocampus [d.f. $=4, F=659.728]$, brainstem [d.f. $=4, F=668.601]$, and prefrontal cortex [d.f. $=4, F=1047.254$ ]) when compared to Group-I control (animals not exposed to RSD). The LPO levels were lower in the drug-treated group (Group-V) compared to the Group-III animals. The values of decreased LPO level in Group-V were not statistically different from Group-I animals.
SOD

The SOD is not evenly distributed in the regions studied as indicated by the control values. The activities of SOD (Fig. 3) were significantly increased in Group-III after $72 \mathrm{~h}$ RSD in discrete regions of the brain (hypothalamus [d.f. $=4, \mathrm{~F}=109.285$ ], hippocampus [d.f. $=4, \mathrm{~F}=40.393$ ], brainstem [d.f. $=4, F=88.777]$, and prefrontal cortex [d.f. $=4, F=18.375]$ ) when compared to Group-I. The SOD activities were lower in the drug-treated group (Group-V) compared to the Group-III animals. The

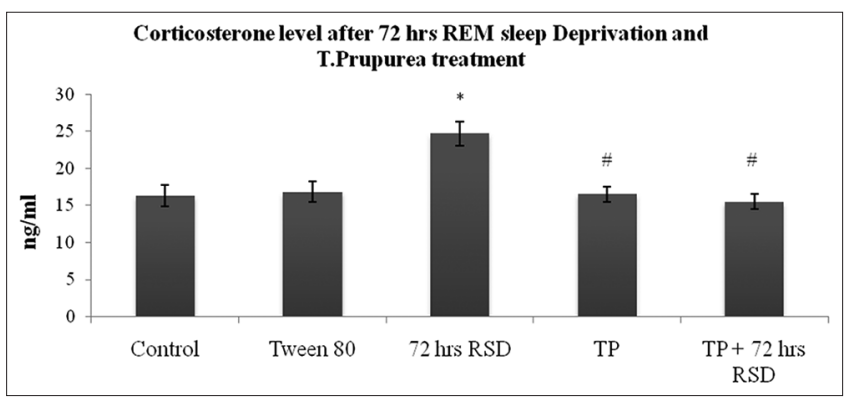

Fig. 1: Data are expressed as mean \pm standard deviation for six rats in each group. The values are expressed $\mathrm{ng} / \mathrm{mL} .{ }^{*}$ Compared with control, \#compared with $72 \mathrm{~h}$ REM sleep deprivation. The symbols represent statistical significance: $*$, \#p<0.05

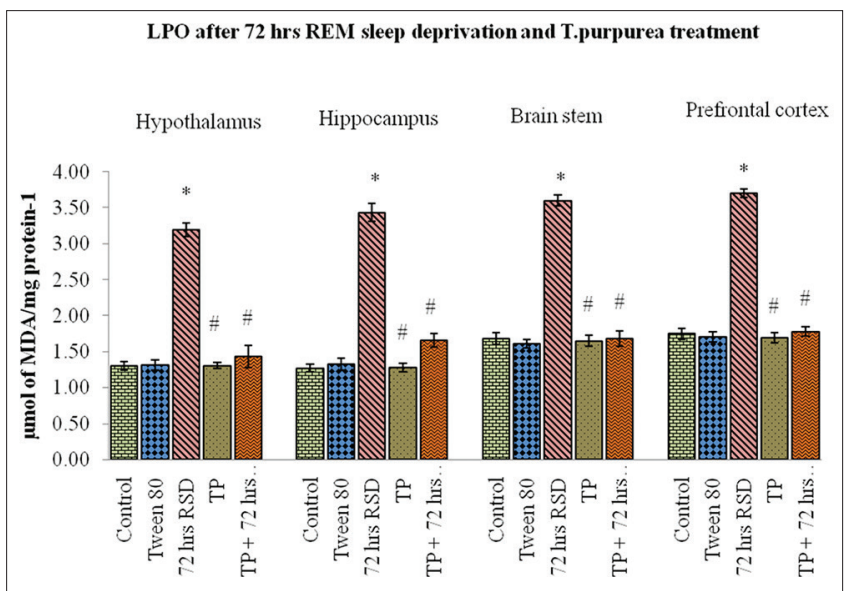

Fig. 2: Data are expressed as mean \pm standard deviation for six rats in each group. The values are expressed $\mu \mathrm{mol}$ of MDA formed mg protein ${ }^{-1}$. *Compared with control, \# compared with 72 h RSD.

The symbols represent statistical significance: * \#p $<0.05$

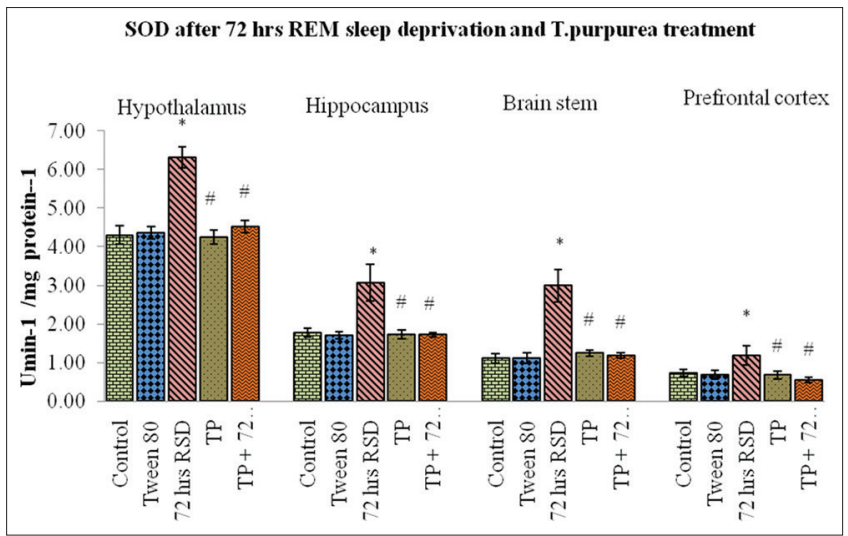

Fig. 3: Data are expressed as mean \pm standard deviation for six rats in each group. The values are expressed $\mathrm{U} / \mathrm{min} \mathrm{mg}_{\text {protein }}{ }^{-1}$.

*Compared with control, \# compared with 72 h REM sleep deprivation. The symbols represent statistical significance: *, $\# \mathbf{p}<0.05$ 
activities of SOD decreased in Group-V were not statistically different from Group-I animals.

\section{CAT}

The results are summarized in Fig. 4. The CAT levels were increased in Group-III animals after $72 \mathrm{~h}$ RSD in discrete regions of the brain (hypothalamus [d.f. $=4, \mathrm{~F}=34.737$ ], hippocampus [d.f. $=4, \mathrm{~F}=51.935]$, brainstem [d.f. $=4, F=26.988]$, and prefrontal cortex [d.f. $=4, F=53.782]$ ) when compared to Group-I. The CAT levels were lower in the drugtreated group (Group-V) compared to the Group-III animals.

\section{GPX}

The results are summarized in Fig. 5. The GPx also showed regional variations among the brain region studied. The GPx levels increased in Group-III after $72 \mathrm{~h}$ RSD in discrete regions of the brain (hypothalamus [d.f. $=4, F=70.217$ ], hippocampus [d.f. $=4, F=152.491]$, brainstem [d.f. $=4$, $\mathrm{F}=8.067$ ], and prefrontal cortex [d.f. $=4, \mathrm{~F}=67.038$ ]) when compared to Group-I. The GPx levels were lower in the drug-treated group (Group-V) compared to the Group-III animals. The values of decreased GPx in Group-V were not statistically different from Group-I animals.

\section{Reduced GSH}

The results are summarized in Fig. 6. The GSH levels were significantly decreased in Group-III animals after $72 \mathrm{~h}$ of RSD in discrete regions of the brain (hypothalamus [d.f. $=4, \mathrm{~F}=14.617$ ], hippocampus [d.f. $=4$,

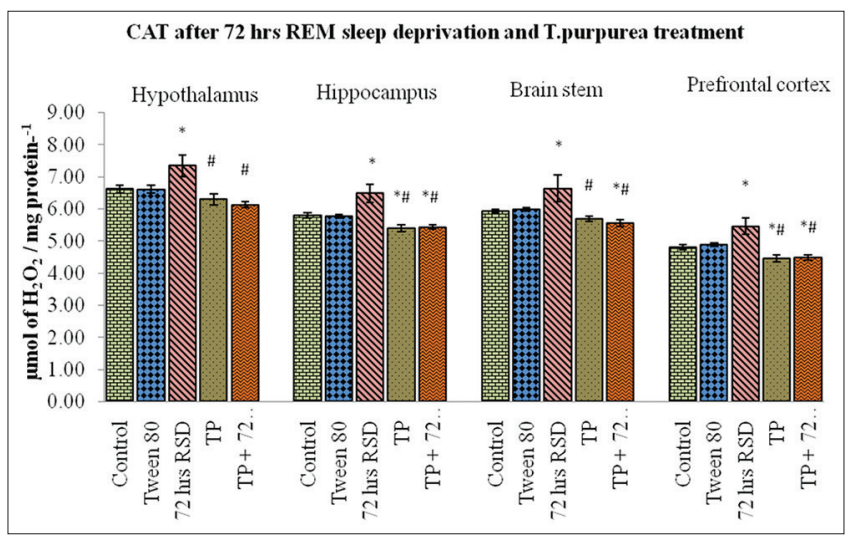

Fig. 4: Data are expressed as mean \pm standard deviation for six rats in each group. The values are expressed $\mu \mathrm{mol}$ of $\mathrm{H}_{2} \mathrm{O}_{2}$ consumed min $^{-1}$ mg protein ${ }^{-1}$. *Compared with control, \# compared with $72 \mathrm{~h}$ RSD. The symbols represent statistical significance: *, \#p<0.05

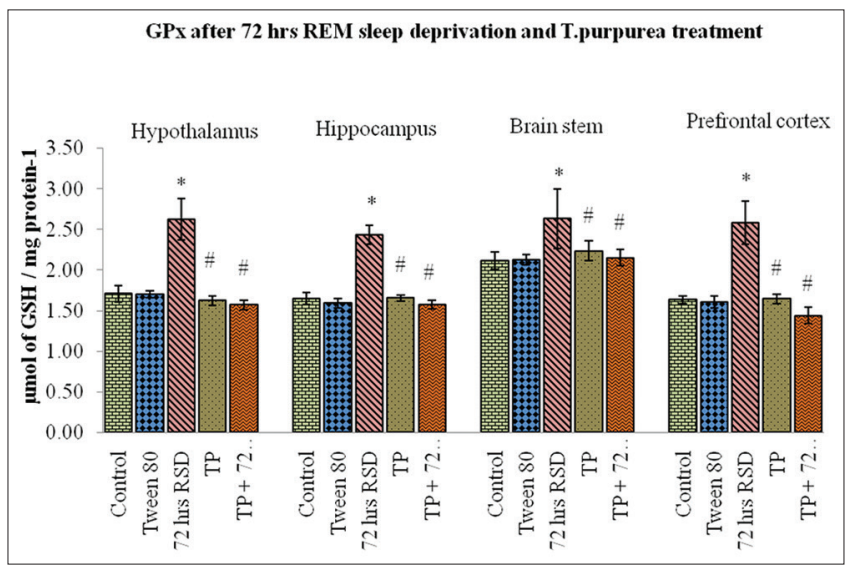

Fig. 5: Data are expressed as mean \pm standard deviation for six rats in each group. The values are expressed $\mu \mathrm{mol}$ of glutathione oxidized min $^{-1}$ mg protein ${ }^{-1}$. Compared with control, \#compared with 72 h RSD. The symbols represent statistical significance: *, $\# \mathbf{p}<0.05$
$\mathrm{F}=31.587$ ], brainstem [d.f. $=4, \mathrm{~F}=52.122$ ], and prefrontal cortex [d.f. $=4$, $\mathrm{F}=28.979]$ ) when compared to Group-I animals. The GSH levels were higher in the drug-treated group (Group-V) compared to the Group-III animals. The values of increased GSH in Group-V were not statistically different from Group-I animals.

\section{Vitamin $C$ and $E$}

Vitamin C (Table 1) and Vitamin E (Table 2) levels were significantly decreased in Group-III animals after $72 \mathrm{~h}$ RSD when compared to Group-I control animals. On the other hand, Vitamin C and Vitamin E levels were higher in the drug-treated group (Group-V), compared to Group-III animals. The values of increased Vitamin C and Vitamin E in Group-V were not statistically different from Group-I animals.

- Vitamin C level after 72 h REM sleep deprivation and T. purpurea treatment.

- Vitamin E level after $72 \mathrm{~h}$ REM sleep deprivation and T. purpurea treatment.

In Group-II and IV animals, all the parameters in all the regions of the brain were not significantly different from Group-I animals.

\section{DISCUSSION}

Many studies have shown that SD-induced oxidative damage in several types of tissues [25]. Further, Lungato et al., stated that SD alters gene expression and antioxidant enzyme activity in mice [26]. Oxidative stress had linked with cognitive impairments [27].

Antioxidants and free radicals scavenging system present in the cell protect against the damaging effects of free radicals [28]. In normal cells, there is a balance exists between oxidative products and antioxidants, such as SOD, CAT, GPx, GSH, and Vitamin C and E. Brain is more vulnerable to oxidative damage due to its high oxygen consumption [29]. For the transmission of impulses between the neuronal cells, it requires energy in the form of ATP, during the production of ATP using oxygen, a small percentage $(<3 \%)$ of oxygen in mitochondria is mindfully converted to superoxide radical this explains the reason for the increased production of free radicals in the brain. Furthermore, stress response results in the creation of some other reactive oxygen species such as hydrogen peroxide $\left(\mathrm{H}_{2} \mathrm{O}_{2}\right)$, hydroxyl radicals $(. \mathrm{OH})$, and superoxide anion radicals $\left(\mathrm{O}_{2}^{-}\right)$that cause LPO, especially in cell membrane leads to tissue damage [30]. The platform technique used for SD raises the possibility that long-term impairment of synaptic plasticity [31].

In the present study, $72 \mathrm{~h}$ RSD are producing marked and increased LPO, SOD, CAT, GPx activities and decreased in the levels of GSH, Vitamin C, and Vitamin E in discrete regions of the brain that were

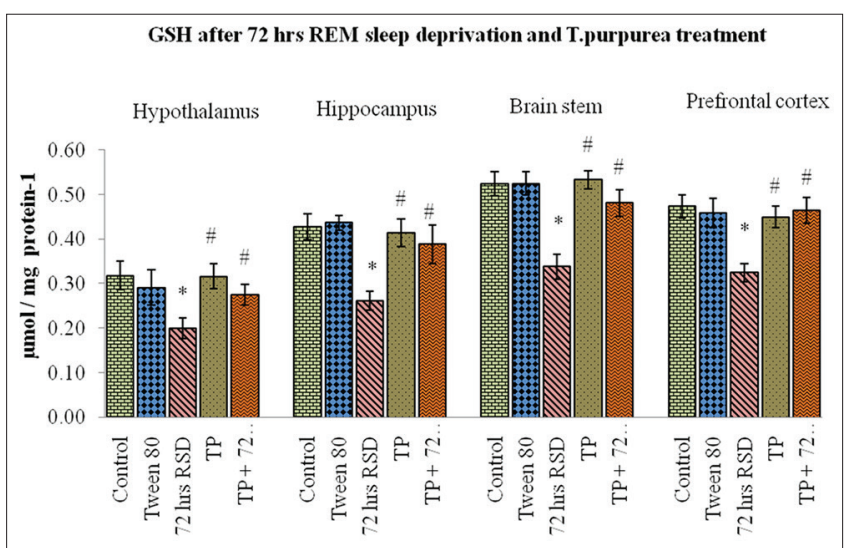

Fig. 6: Data are expressed as mean \pm standard deviation for six rats in each group. The values are expressed $\mu \mathrm{mol} \mathrm{mg}$ protein $^{-1}$.

* Compared with control, \#compared with 72 h REM sleep deprivation. The symbols represent statistical significance: *, $\# \mathbf{p}<0.05$ 
Table 1: Data are expressed as mean \pm STDEV for six rats in each group

\begin{tabular}{lllll}
\hline Brain regions & Group I & Group II & Group III & Group IV \\
\hline Hypothalamus (d.f.=4, F=317.124) & $338.50 \pm 8.30$ & $338.88 \pm 5.12$ & $231.56 \pm 6.48^{*}$ & $345.70 \pm 5.88 \#$ \\
Hippocampus (d.f.=4, F=153.482) & $394.50 \pm 4.02$ & $389.30 \pm 5.82$ & $286.25 \pm 11.06^{*}$ & $380.50 \pm 10.17 \#$ \\
Brain stem (d.f.=4, F=220.853) & $291.31 \pm 4.98$ & $292.90 \pm 5.39$ & $220.48 \pm 5.68^{*}$ & $286.25 \pm 4.99 \#$ \\
Prefrontal cortex (d.f.=4, F=289.817) & $487.16 \pm 6.35$ & $479.58 \pm 12.47$ & $327.21 \pm 5.73^{*}$ & $475.50 \pm 13.47 \#$ \\
\hline
\end{tabular}

The values are expressed $\mu \mathrm{g} / \mathrm{g}$ tissue ${ }^{-1}{ }^{*}$ Compared with control, \#Compared with $72 \mathrm{~h}$ RSD. The symbols represent statistical significance: ${ }^{*}, \# \mathrm{p}<0.05$

T. purpurea: Tephrosia purpurea, RSD: REM sleep deprivation

Table 2: Data are expressed as mean $\pm \mathrm{STDEV}$ for six rats in each group

\begin{tabular}{lllll}
\hline Brain regions & Group I & Group II & Group III & Group IV \\
\hline Hypothalamus (d.f.=4, F=21.758) & $11.90 \pm 1.16$ & $11.72 \pm 0.82$ & $7.89 \pm 0.70^{*}$ & $11.16 \pm 0.51 \#$ \\
Hippocampus (d.f.=4, F=48.613) & $17.53 \pm 0.73$ & $17.36 \pm 0.68$ & $11.25 \pm 0.72^{*}$ & $16.25 \pm 1.33 \#$ \\
Brain stem (d.f.=4, F=80.482) & $14.82 \pm 0.93$ & $15.31 \pm 0.94$ & $8.64 \pm 0.42 *$ & $11.25 \pm 0.95 \#$ \\
Prefrontal cortex (d.f.=4, F=69.133) & $18.91 \pm 0.88$ & $18.73 \pm 0.68$ & $12.43 \pm 0.70^{*}$ & $16.51 \pm 0.60^{*} \#$ \\
\hline
\end{tabular}

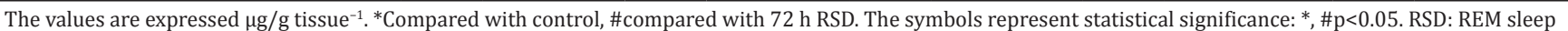
deprivation

tested (hypothalamus, hippocampus, brainstem, and prefrontal cortex). Further, it also significantly increases the corticosterone level in plasma.

Acute exposure to stress leads to an excessive generation of oxygen free radicals this might be the reason for the production of the excess amount of LPO [32]. SOD is a major intracellular enzyme, which protects the cell against oxygen free radicals by speeding up its dismutation of the superoxide anion (02--). In recent study states that the redoxsensitive transcription factor NF-E2-related factor 2 (Nrf2) plays an important role in activating antioxidant enzymes, the increased SOD activity could be due to the activation of Nrf2 induced by SD [33]. CAT was responsible for the detoxification of significant amounts of $\mathrm{H}_{2} \mathrm{O}_{2} \mathrm{so}$, CAT level was increased in $72 \mathrm{~h}$ RSD.

GPx is a major antioxidant enzyme in many tissues, especially in the brain, which metabolizes peroxides, such as $\mathrm{H}_{2} \mathrm{O}_{2}$ and protects cell membranes from LPO [34]. GPx activity in the brain is more important than CAT for the destruction of $\mathrm{H}_{2} \mathrm{O}_{2}$ because this enzyme was more in mitochondria and cytosol. The GSH levels were significantly reduced in SD animals; this might be due to its multiple activities in scavenging the free radicals produced by SD, which leads to its greater consumption [35]. In the present study also the GSH level was significantly reduced in the $72 \mathrm{~h} \mathrm{SD}$.

Vitamin C acts as a powerful scavenger of superoxide -induced LPO. Endogenous Vitamin $\mathrm{C}$ and $\mathrm{E}$ levels have been reported to decline under stress conditions [36]. Plants have both enzymatic and nonenzymatic systems to scavenge active oxygen species. Vitamin $\mathrm{C}$ and $\mathrm{E}$ are non-enzymatic compounds can protect the human body from free radicals [37].

Vitamin $\mathrm{E}$ is a powerful antioxidant that inhibits the free radical reaction and prevents oxidative stress [38]. Further, Vitamin E administration to an animal model of diabetes normalizes the GSH level and activities of GPx, CAT, and SOD [39].

In the present study, TP treated sleep-deprived animals showed a marked decrease in SOD, GPx, and CAT activity when compared with sleep-deprived animals. The further LPO level was also significantly decreased in the TP treated sleep-deprived animals. GSH, Vitamin C, and Vitamin E level were significantly increased in the TP treated sleepdeprived animals when compared with the sleep-deprived animals.

The leaves of TP contain the flavonoids, ( + ) -tephrorins A and B, and (+) -tephrosone [40]. Furthermore, it has anti-inflammatory activit [41], antimicrobial activity [42], an antidiabetic activity [43], cytotoxic activity [44], antiviral activity [45], a nephroprotective activity [46], and hepatoprotective activity [47]. The anticancer activity of TP was evaluated using MCF 7 cell lines [48].

\section{CONCLUSION}

The observed data confirmed the presence of oxidative damage in the discrete regions of the brain when exposed to $72 \mathrm{~h}$ RSD. The significant variations in SOD, LPO, CAT, GPx, GSH, Vitamin C, Vitamin E, and corticosterone were normalized by an ethanolic extract of TP in the rat. Further, there was no adverse effect found in the rat model of treatment with TP alone. In future, it is necessary to conduct more extensive studies with TP to explicate their molecular mechanism in antioxidant activity.

\section{ACKNOWLEDGMENT}

The authors are grateful to the University of Madras for providing the infrastructure to conduct the research.

\section{AUTHORS CONTRIBUTIONS}

All the authors have contributed equally.

\section{CONFLICTS OF INTEREST}

The authors declare that they have no conflicts of interest concerning this research article.

\section{REFERENCES}

1. Siegel JM. Sleep viewed as a state of adaptive inactivity. Nat Rev Neurosci 2009;10:747.

2. Ramanathan L, Gulyani S, Nienhuis R, Siegel JM. Sleep deprivation decreases superoxide dismutase activity in rat hippocampus and brain stem. Neuroreport 2002:13:1387-90.

3. Elsevier Saunders Publications. Guyton and Hall, Textbook of Medical Physiology. International $11^{\text {th }}$ ed. Philadelphia, PA: Elsevier Saunders Publications; 2006. p. 739-41.

4. Walker MP, Stickgold R. Sleep-dependent learning and memory consolidation. Neuron 2004;44:121-33.

5. Van Der Werf YD, Altena E, Schoonheim MM, Sanz-Arigita EJ, Vis JC, De Rijke W, et al. Sleep benefits subsequent hippocampal functioning. Nat Neurosci 2009;12:122-3.

6. Aleisa AM, Helal G, Alhaider IA, Alzoubi KH, Srivareerat M, Tran TT, et al. Acute nicotine treatment prevents REM sleep deprivationinduced learning and memory impairment in rat. Hippocampus 2011;21:899- 909

7. Alhaider IA, Aleisa AM, Tran TT, Alzoubi KH, Alkadhi KA. Chronic caffeine treatment prevents sleep deprivation-induced impairment of cognitive function and synaptic plasticity. Sleep 2010;33:437-44.

8. Porter NM, Bohannon JH, Curran-Rauhut M, Buechel HM, Dowling AL, Brewer LD, et al. Hippocampal CA1 transcriptional profile of sleep deprivation: Relation to aging and stress. PLoS One 2012;7:e40128.

9. Hutchison BL, Stone PR, McCowan LM, Stewart AW, Thompson JM, Mitchell EA, et al. A postal survey of maternal sleep in later pregnancy. 
BMC Pregnancy Childbirth 2012;12:144

10. Kanga WS, Parkb HJ, Chungb JH, Kima JW. REM sleep deprivation increases the expression of interleukin genes in mice hypothalamus. Neurosci Lett 2013;556:73-8.

11. Colten HR, Altevogt BM. Institute of Medicine (US) Committee on Sleep Medicine and Research, Sleep Disroders and Sleep Deprivation: An Unmet Public Health Problem. Extent and Health Consequences of Chronic Sleep Loss and Sleep Disorders. Vol. 3. Washington, DC: National Academies Press (US); 2006.

12. Lodhi S, Pawar RS, Jain Ap, Singhai AK. Wound healing potential of Tephrosia purpurea (Linn.) Pers. in rats. J Ethnopharmacol 2006;108:204-10.

13. Despande SS, Shah GB, Parmar NS. Antiulcer activity of Tephrosia purpurea in rats. Indian J Pharmacol 2003;35:168-72.

14. Asuntha G, Prasannaraju Y, Sujatha D, Prasad KV. Assessment of effect of ethanolic extract of Tephrosia purpurea (L.) Pers., Fabaceae, activity on lithium-pilocarpine induced status epilepticus and oxidative stress in Wistar rats. Rev Bras Farmacog Braz J Pharmacogn 2010;20:767-72.

15. Hajali V, Sheibani V, Esmaeili-Mahani S, Shabani M. Female rats are more susceptible to the deleterious effects of paradoxical sleep deprivation on cognitive performance. Behav Brain Res 2012;228:311- 8

16. Machado RB, Hipólide DC, Benedito-Silva AA, Tufik S. Sleep deprivation induced by the modified multiple platform technique: Quantification of sleep loss and recovery. Brain Res 2004;1004:45-51.

17. Ohkawa H, Ohishi N, Yagi K. Assay for lipid peroxidation in animal tissue by the thiobarbituric acid reaction. Anal Biochem 1979;95:351-8.

18. Marklund S, Marklund G. Involvement of the superoxide anion radical in the autoxidation of pyrogallol and a convenient assay for superoxide dismutase. Eur J Biochem 1974;47:469-74.

19. Sinha AK. Calorimetric assay of catalase. Anal Biochem 1972;47:389- 94

20. Rotruck JT, Pope AL, Ganther HE, Swanson AB, Hafeman DG, Hoekstra WG. Selenium biochemical role as a component of glutathione peroxidase. Science 1973;179:588-90.

21. Moron MS, Depierre JW, Mannervik B. Levels of glutathione, glutathione reductase and glutathione-S-transferase activities in rat lung and liver. Biochim Biophys Acta 1979;582:67-78.

22. Omaye ST, Turnbull JD, Sauberlich HE. Selected methods for the determination of ascorbic acid in animal cells, tissues, and fluids. Methods Enzymol 1979;62:3-11.

23. Desai ID. Vitamin E analysis method for animal tissues. Methods Enzymol 1984;105:138-43

24. Lowry OH, Rosenbrough NJ, Farr AL, Randall RJ. Protein measurement with the Folin-phenol reagent. J Biol Chem 1951;193:265-75.

25. Everson CA, Laatsch CD, Hogg N. Antioxidant defense responses to sleep loss and sleep recovery. Am J Physiol Regul Integr Comp Physiol 2005;288:R374-83

26. Lungato L, Marques MS, Pereira VG, Gazarini ML, Tufik S, Almeida V D. Sleep deprivation alters gene expression and antioxidant enzyme activity in mice splenocytes. Scandinavian J Immunol 2013;77:195-9.

27. Butterfield DA, Drake J, Pocernich C, Castegna A. Evidence of oxidative damage in Alzheimer's disease brain: The central role for amyloid beta-peptide. Trends Mol Med 2001;7:548-54

28. Naritsara T, Pannapa P, Pattra S. Evaluation of antioxidant and antibacterial activities of fresh and freeze-dried selected fruit juices. Asian J Pharm Clin Res 2017;10:156-60.
29. Floyd RA, Carney JM. Free radical damage to protein and DNA: Mechanism involved and relevant observation on brain undergoing oxidative stress. Ann Neurol 1992;32 Suppl: S22-7.

30. Beckman K, Ames B. The free radical theory of aging matures. Physiol Rev 1998;78:548-81.

31. McEwen BS. The neurobiology of stress: From serendipity to clinical relevance. Brain Res 2000;886:172-89.

32. Aravind KN, Mathangi DC, Namasivayam A. Noise-induced changes in free radical scavenging enzymes in the blood and brain of albino rats. Med Sci Res 1998;26:811-2

33. Na HK, Kim EH, Jung JH, Lee HH, Hyun JW, Surh YJ. Epigallocatechin gallate induces Nrf2-mediated antioxidant enzyme expression via activation of PI3K and ERK in human mammary epithelial cells. Arch Biochem Biophys 2008;476:171-7.

34. Walden LR, Reiter RJ, Abe M. Melatonin stimulates brain glutathione peroxidase activity. Neurochem Int 1995;26:497-502.

35. Sokolovsk VV, Goncharova LL, Kiseliva NN, Radionova LP. The antioxidant system noise induced stress. J Med Khim 1987;33:111-3.

36. Acharya S, Acharya UR. In vivo lipid peroxidation responses of tissues in lead-treated Swiss mice. Ind Health 1997;35:542-4.

37. Pradeesh S, Swapna TS. Antioxidant activity in leaves of Sesbania grandiflora(L.) Pers. Asian J Pharm Clin Res 2018;11:116-9.

38. Packer L. Vitamin E is nature's master antioxidant. Sci Am 1994:1:54- 63

39. Tiwari V, Kuhad A, Bishnoi M, Chopra K. Chronic treatment with tocotrienol, an isoform of Vitamin E, prevents intracerebroventricular streptozotocin-induced cognitive impairment and oxidative-nitrosative stress in rats. Pharmacol Biochem Behav 2009;93:183-9.

40. Hegazy ME, Abd el-Razek MH, Nagashima F, Asakawa Y, Paré PW. Rare prenylated flavonoids from Tephrosia purpurea. Phytochemistry 2009;70:1474-7.

41. Gulecha V, Shivkumar T, Kandere R, Upasani C. Tephrosia purpurea purpurea Linn. Leaves attenuated pain and inflammation in experimental animals. Int J Nutr Pharmacol Neurol Dis 2011:1:146-51.

42. Partha N, Snigdha P, Laxmidhar M. Formulation development and in vitro evaluation of dental gel containing ethanol extract of Tephrosia purpurea Linn. Int J Pharm Pharm Sci 2016;8:132-41.

43. Pavana PB, Sethupathy SA, Santha KA, Manoharan S. The effect of Tephrosia purpurea aqueous seed extract on blood glucose and antioxidant enzyme activity in the streptozocin-induced diabetic rat. Afr J Tradit Complment Altern Med 2009;6:78-86.

44. Subhadra S, Venkata RK, Vinod KR, Parre SK, Chintala S, Rajeswar T. Comparative toxicity assessment of three classes of three Tephrosia species on Artemia salina and animal cell lines. J Nat Pharm 2011;2:143-8

45. Kokila AP, Patel AN, Prajapati SN. Preliminary phytochemical screening and study of antiviral activity and antibacterial activity of Tephrosia purpurea flower. Life Sci Leaf 2010;1:7-13.

46. Saleem M, Ahmed Su, Alam A, Sultana S. Tephrosia purpurea alleviates phorbol ester-induced tumor promotion response in murine skin. Pharmacol Res 2001;43:135-44.

47. Deepa K, Praboth V, Patel SS. Hepatoprotective effect of a virgoliv syrup against ccl4 induced hepatic injury in rats. Int J Pharm Pharm Sci 2015;7:221-6.

48. Gulecha V, Sivakumar T. The anticancer activity of Tephrosia purpurea and Ficus religiosa using MCF 7 cell lines. Asian Pac J Trop Med 2011;4:526-9. 